\title{
Morphology and the natural history of cribriform adenocarcinoma (adenoid cystic carcinoma)
}

\author{
D. A. OSBORN \\ From the Institute of Laryngology and Otology, University of London
}

SUMMARY Forty-three examples of cribriform adenocarcinoma (adenoid cystic carcinoma) of mixed glandular origin are reported. Structural studies emphasise the classical cribriform pattern which indicates the capacity of this neoplasm to behave as both an epithelial and a connective tissue type tumour. In terms of survival, it does not appear to be as malignant as other forms of carcinoma arising in similar anatomical locations. The five-year crude survival rate $(56 \%)$ compares favourably with that of other carcinomas of the palate and paranasal sinuses. A recurrence rate of the order of $20 \%$ may persist up to 10 years after primary treatment, and while this is not inimical to longer survival there is clearly a high morbidity.

This well-recognised tumour of exocrine glands was first described by Billroth in 1856 under the name 'Zylindrome'. Subsequently, many alternative names have been proposed and, although the term 'cylindroma' is still in common use, Friedmann and Osborn (1966) introduced the expression 'cribriform adenocarcinoma' as being more appropriate to its origin, morphology, and behaviour. More recently, however, the WHO Subcommittee on classification of tumours recommended adoption of the term 'adenoid cystic carcinoma' which was first used by Reid (1952). The widespread distribution in the upper alimentary and respiratory tracts underlines its origin more particularly in mucosal as compared with major salivary glands. Morphological similarity to tumours in other locations has led inevitably to some blurring of the general picture and, although the malignant character of most of these tumours is no longer in doubt, the behavioural pattern still requires elucidation and definition.

\section{Material and methods}

Between 1948 and 1973 the pathological records of the Institute of Laryngology and Otology acquired 129 tumours arising in mucosal glands and, of these, $34(26 \%)$ were cribriform adenocarcinomas. During the same period, five examples of similar structure were seen in neoplasms of major salivary glands $(5 \%)$ while a further four $(23 \%)$ were found in a

Received for publication 28 July 1976 group of tumours of the external auditory meatus designated ceruminomas.

Light microscopy was carried out on all cases and material was available for electron microscopy in one parotid, one ceruminous, and five mucosal gland tumours. Paraffin sections were stained with haematoxylin and eosin, Alcian Blue, PAS/diastase, toluidine blue/hyaluronidase, Van Gieson, and PTAH. Material fixed in buffered glutaraldehyde (Sabatini et al., 1963) and postfixed in osmium tetroxide was embedded in Araldite. Sections were cut on an LKB microtome (pale gold to silver), stained with aqueous uranyl acetate and lead citrate, and examined under an AEI Corinth 275 electron microscope.

\section{Results}

The anatomical distribution in the mucosal gland group is shown in Table 1 in which it can be seen that the major sites were the palate and maxillary sinus. The five major gland tumours were all of parotid origin. Twenty-five of the cases were females, and Table 2 shows that the age distribution was broadly based, an appreciable number of cases presenting at a relatively early age. Furthermore, when the age-specific incidence was calculated it was found to be maximal in the fourth decade.

The cases of palatal origin presented with local swelling of variable duration ranging from one month to two years but, in the majority, not exceeding six months. In the antral group, facial pain and 
Table 1 Cribriform adenocarcinomas of mucosal gland origin: anatomical distribution

\begin{tabular}{lc}
\hline Site & No. \\
\hline Palate & 11 \\
Maxillary sinus & 10 \\
Ethmoid sinus & 1 \\
Nasal cavity & 1 \\
Nasopharynx & 4 \\
Trachea & 2 \\
Tongue & 2 \\
Oropharynx & 1 \\
Lachrymal gland & 2 \\
& Total 34 \\
\hline
\end{tabular}

Table 2 Cribriform adenocarcinomas: age distribution and incidence

\begin{tabular}{lllllllll}
\hline Decade & 1 & 2 & 3 & 4 & 5 & 6 & 7 & 8 \\
\hline $\begin{array}{l}\text { Age } \\
\text { distribution }\end{array}$ & 0 & 0 & 5 & 9 & 9 & 8 & 8 & 4 \\
$\begin{array}{l}\text { Age specific } \\
\text { incidence }^{1}\end{array}$ & & 0.83 & 1.81 & 1.68 & 1.50 & 1.63 & 0.95 \\
\hline
\end{tabular}

${ }^{1}$ Based on the estimated population in the South Metropolitan Cancer Registry area (Registrar General's Statistical Review, 1970)

swelling were common forms of presentation, and the duration ranged from two months to four years, over $50 \%$ giving a history of one year or more. In the nasopharyngeal cases, nasal obstruction, deafness and diplopia were common symptoms which had been present for six weeks to two years. In cases involving the major salivary glands, swelling had been present for periods ranging from three to 12 years, only one patient (the youngest) having a history of less than six years. The aural cases presented with pain or swelling in the external auditory meatus of one to three years' duration.

\section{GROSS APPEARANCES}

The demarcation of these tumours varied greatly. Palatal tumours were often lobulated, sometimes sufficiently discrete to be described as having 'shelled out' but in others the boundaries were obscured by infiltration of the surrounding tissues. In antral cases the sinus was filled with solid tumour tissue showing varying degrees of mural involvement. The cut surface revealed unremarkable, solid white growth which was usually readily distinguishable from the other common glandular tumour, the pleomorphic or 'mixed' type, by virtue of the absence of semitranslucent areas indicative of the chondromyxoid component in the latter.

\section{MICROSCOPY}

The structural features of these tumours can be divided into four main patterns as follows:

1 Common to all is the typical cribriform appearance due to the presence of numerous microcystic spaces (Fig. 1). The latter often contain mucoid

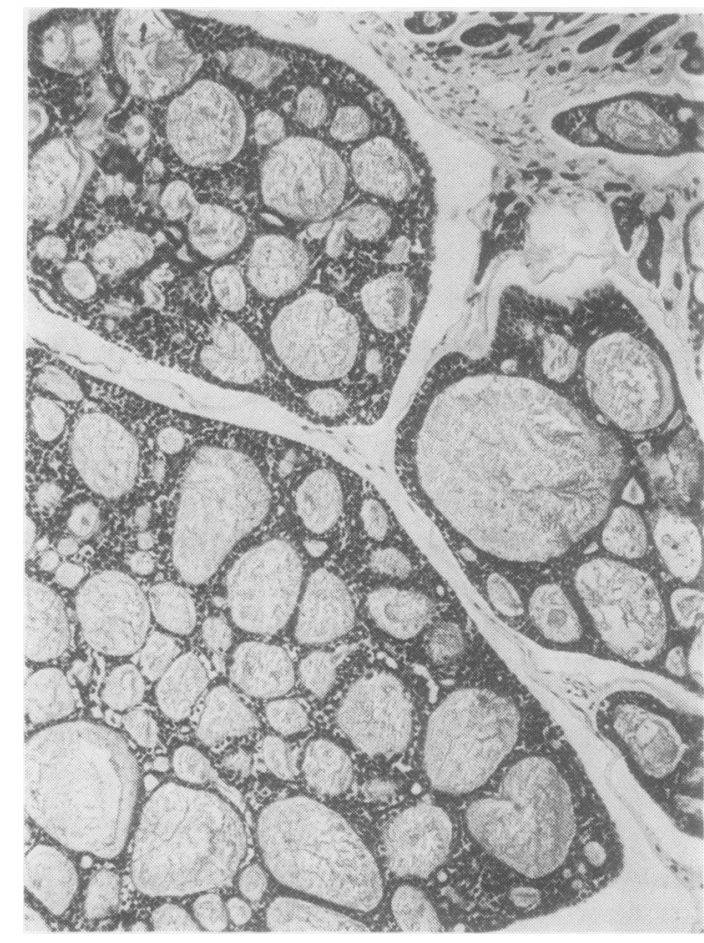

Fig. 1 Case 19. Cribriform adenocarcinoma of maxillary sinus. Pseudolumina constituting the classical cribriform pattern. Haematoxylin and eosin $\times 100$.

material exhibiting the histochemical reactions of connective tissue type mucin and, in so far as such spaces lack a definitive epithelial lining, they have been conveniently designated pseudolumina (Azzopardi and Smith, 1959), a term which receives additional support from ultrastructural studies. Under the electron microscope there is a notable lack of microvilli which often characterise an epithelial lumen, but the pseudolumen frequently contains a well-defined layer of amorphous material resembling a basal lamina (Fig. 2), and sometimes the bordering cells contain bundles of filaments resembling either tonofilaments or myofilaments while desmosomal attachments are frequently seen. Collagen and even cells resembling fibroblasts may sometimes be found in the pseudolumina.

2 Contrasting with the pseudolumina are the not infrequent tubular structures lined by clearly defined cubical epithelium and often containing material showing the staining reactions of epithelial type mucin. Sometimes seen within cellular masses, they often appear more isolated when the darkly stained surrounding cells are reduced to a single layer (Fig. 3). These are true lumina, characteristically 


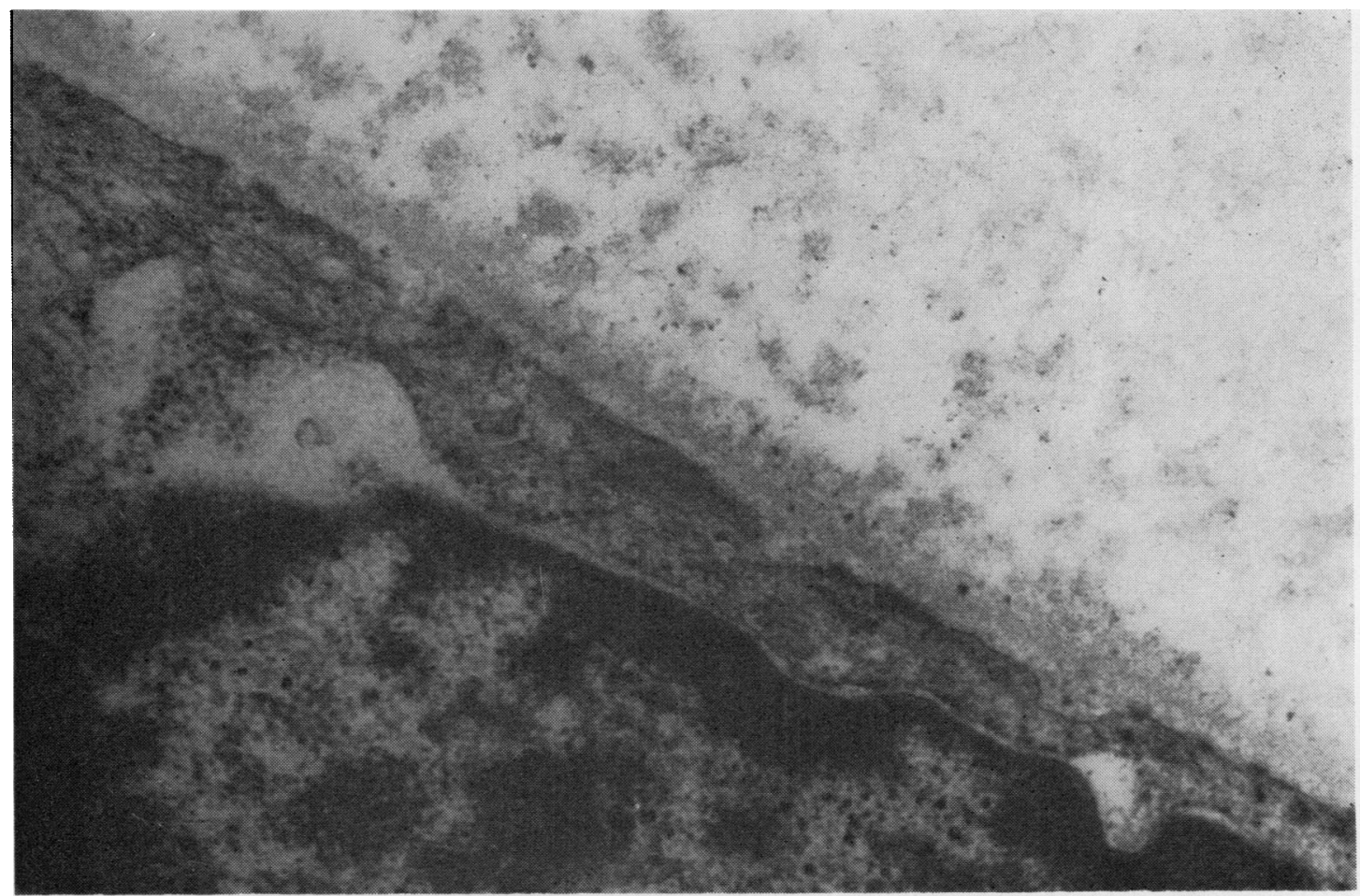

Fig. 2 Case 45. Cribriform adenocarcinoma of hard palate. Cell bordering pseudolumen. Microvilli are absent and a concentration of amorphous material resembles a basal lamina. The cytoplasm contains numerous loosely arranged filaments of the order of $75 \mathrm{~A}$ in diameter. Occasional denser zones of the basal plasma membrane suggest the formation of hemidesmosomes. Many fine particles are consistent with glycogen. $\times 48750$.

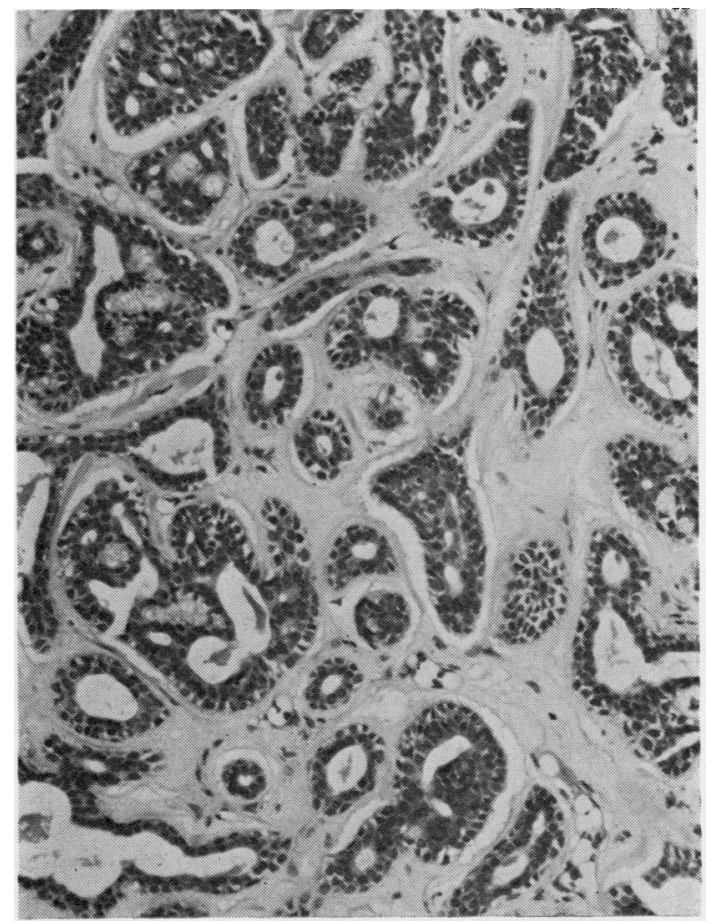

Fig. 3 Case 249. Cribriform adenocarcinoma of nasopharynx. Predominance of true lumina containing eosinophilic material. $H$ and $E \times 160$. 


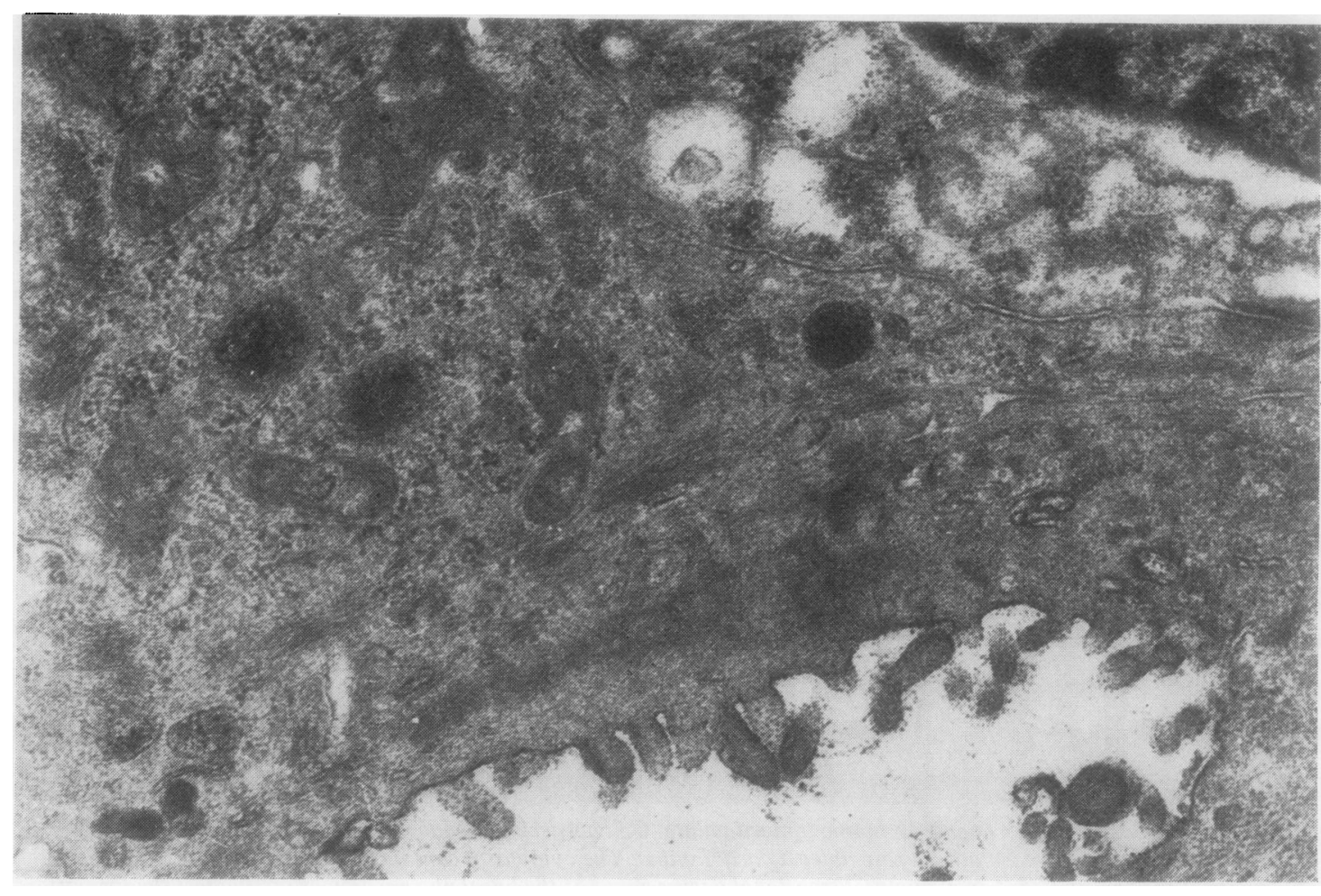

Fig. 4 Case 254. Cribriform adenocarcinoma of hard palate. Cell bordering true lumen showing well developed microvilli and many loose bundles of fine filaments, 40 to $50 \mathrm{~A}$ in diameter. $\times 37500$.

lined by microvilli (Fig. 4). Again, the bordering cells may show filamentous bundles not necessarily related to desmosomes. Cells on the periphery of true lumina may show typical features of myoepithelial cells with numerous bundles of fine filaments.

3 Tumour masses, which always tend to be sharply circumscribed, occasionally present a solid appearance composed of the same small, darkly staining cells found between pseudolumina in cribriform areas (Fig. 5). Sometimes larger, more palely staining cells of squamoid appearance may be seen in such masses, and marginal cells may present a clear form though this is partly illusory due to shrinkage. The fine structure of the constituent cells is variable. Many have no particular characteristics but some display the heavy, fused, filamentous bundles resembling the tonofibrils of squamous cells and occasionally the paraphernalia of secretory cells (profiles of rough endoplasmic reticulum and secretory granules). Particulate material resembling glycogen granules and unspecifiable filaments are often present.

4 The stroma varies greatly in amount and consistency, ranging from scanty loose connective tissue to a densely fibrous background. Although occasionally myxomatous, it never shows the myxochondroid appearance so characteristic of the pleomorphic tumour. A frequent, though not invariable, feature is the presence of hyaline material surrounding or surrounded by the epithelial component (Fig. 6). Such material often stains poorly but may show the staining reactions of collagen and sometimes exhibits a positive PAS reaction. When it is surrounding groups of tumour cells, this material constitutes the 'glashelle Zylinder' of Billroth from which the $N$ well-known term 'cylindroma' was derived. Under N the electron microscope the walls of the cylinder $N$ present a partly amorphous, partly laminated $\omega$ appearance, giving a superficial impression of fibrillar structure (Fig. 7). However, these 'fibrils' show no evidence of the periodic banding charac- $\Phi$ teristic of collagen although such material may be identifiable on the periphery.

BEHAVIOURAL PATTERN

All cases were treated by varying combinations of $\stackrel{\mathbb{Q}}{\varrho}$ surgery and irradiation, the former usually preceding the latter though not necessarily of a radical nature 


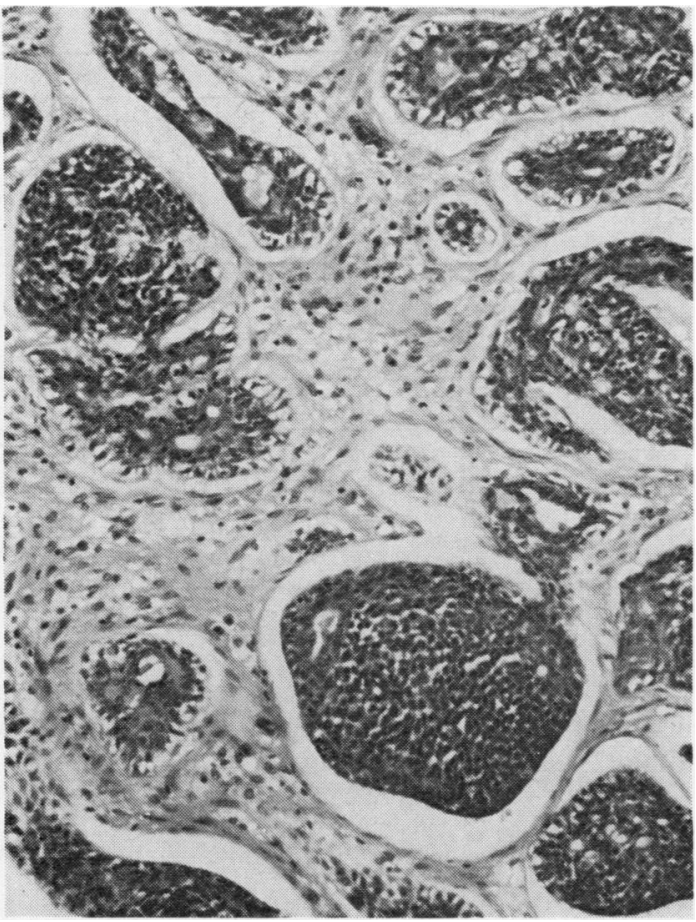

Fig. 5

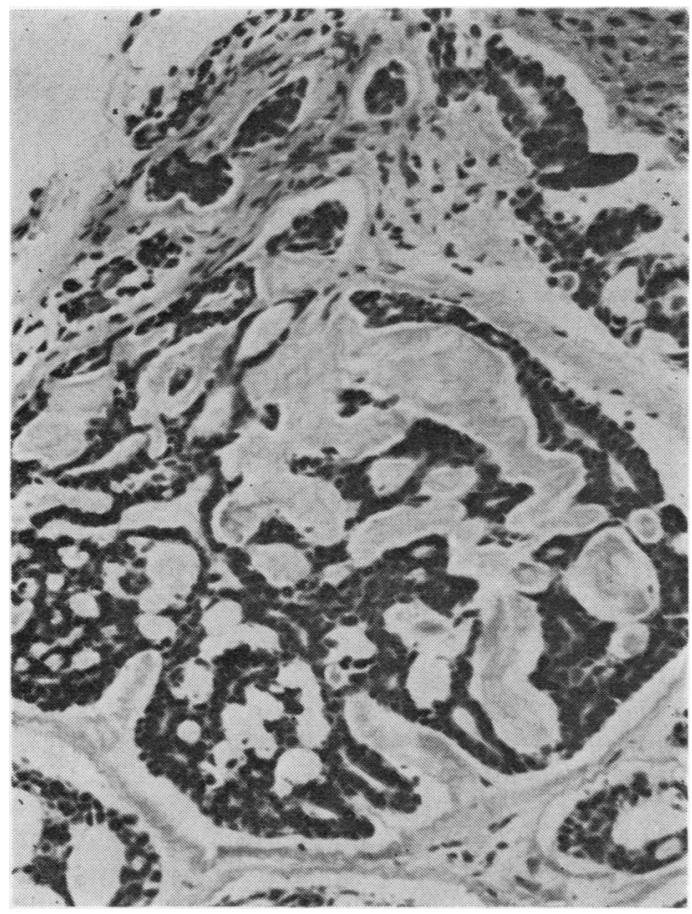

Fig. 6

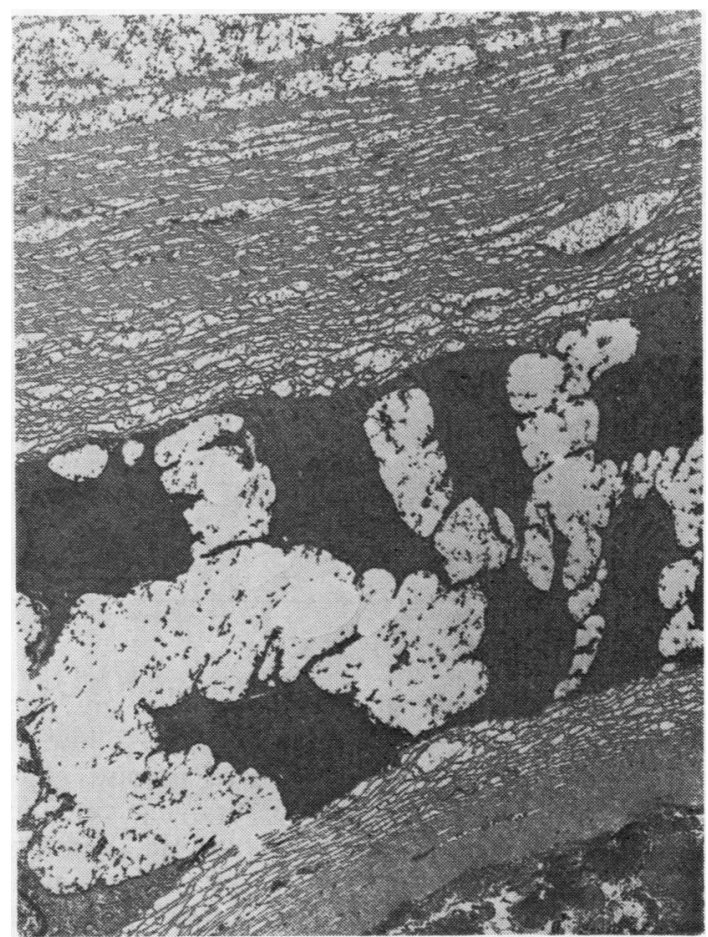

Fig. 7

Fig. 5 Case 115. Cribriform adenocarcinoma of maxillary sinus. Area of solid cellular growth sharply demarcated from the stroma by shrinkage spaces and showing peripheral 'clear' cells. $H$ and $E \times 145$.

Fig. 6 Case 19. Cribriform adenocarcinoma of maxillary sinus. Hyaline stroma intimately related to the epithelial component and forming 'cylinders' and enclavements. Van Gieson $\times 250$.

Fig. 7 Case 254. Cribriform adenocarcinoma of hard palate. Longitudinal section through a 'cylinder'.Tumour cells surrounded by partly amorphous, partly fibrillar material. $\times 3000$. 
Table 3 Cribriform adenocarcinoma: follow-up

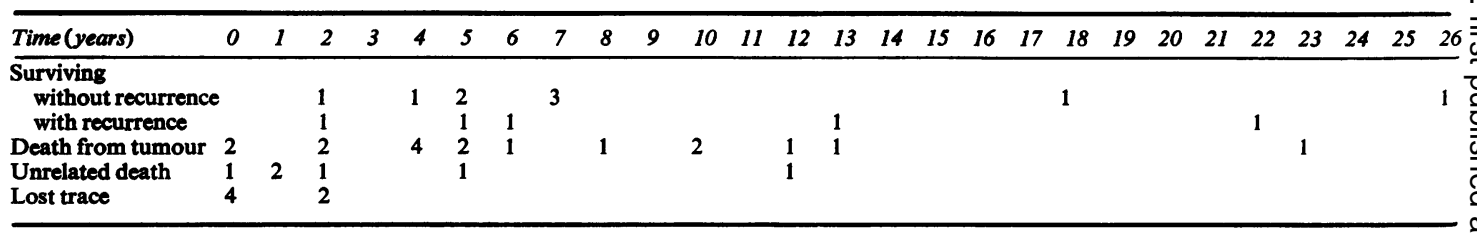

Table 4 Recurrence in cribriform adenocarcinomas

\begin{tabular}{|c|c|c|c|c|c|c|c|c|c|c|c|c|c|c|c|c|c|c|c|c|c|c|c|}
\hline \multirow[b]{2}{*}{ Interval $(y r)$} & \multicolumn{22}{|c|}{ Totals at yearly intervals after primary treatment } & \\
\hline & 1 & 2 & 3 & 4 & 5 & 6 & 7 & 8 & 9 & 10 & 11 & 12 & 13 & 14 & 15 & 16 & 17 & 18 & 19 & 20 & 21 & 22 & $23 ?$ \\
\hline $\begin{array}{l}\text { Total cases alive at each interval } \\
\text { Recurrences }\end{array}$ & 40 & 38 & 35 & 35 & 31 & 28 & 27 & 27 & 26 & 26 & 24 & 24 & 22 & 21 & 21 & 21 & 21 & 21 & 20 & 20 & 20 & 20 & $19 \stackrel{c}{c}$ \\
\hline Number & $\begin{array}{r}9 \\
22\end{array}$ & $\begin{array}{r}6 \\
16\end{array}$ & $\begin{array}{r}6 \\
17\end{array}$ & $\begin{array}{r}6 \\
17\end{array}$ & $\begin{array}{r}3 \\
10\end{array}$ & $\begin{array}{l}2 \\
7\end{array}$ & $\begin{array}{l}\mathbf{0} \\
\mathbf{0}\end{array}$ & $\begin{array}{l}2 \\
7\end{array}$ & $\begin{array}{r}3 \\
11\end{array}$ & $\begin{array}{r}6 \\
23\end{array}$ & $\begin{array}{l}\mathbf{0} \\
\mathbf{0}\end{array}$ & $\begin{array}{l}1 \\
4\end{array}$ & $\begin{array}{l}1 \\
4\end{array}$ & $\begin{array}{l}\mathbf{0} \\
\mathbf{0}\end{array}$ & $\begin{array}{l}\mathbf{0} \\
\mathbf{0}\end{array}$ & $\begin{array}{l}\mathbf{0} \\
\mathbf{0}\end{array}$ & $\begin{array}{l}\mathbf{0} \\
\mathbf{0}\end{array}$ & $\begin{array}{l}\mathbf{0} \\
\mathbf{0}\end{array}$ & $\begin{array}{l}1 \\
5\end{array}$ & $\begin{array}{l}\mathbf{0} \\
\mathbf{0}\end{array}$ & $\begin{array}{l}\mathbf{0} \\
\mathbf{0}\end{array}$ & $\begin{array}{l}\mathbf{0} \\
\mathbf{0}\end{array}$ & \\
\hline
\end{tabular}

in the first instance. The follow-up data are summarised in Table 3. Of the six cases lost to follow-up, four were mucosal and two were parotid gland tumours while the 14 currently surviving cases included 10 mucosal gland, two parotid, and two aural tumours. Six cases, all in the mucosal gland group, have died from unrelated causes. Recurrence is known to have taken place in $\mathbf{1 6}$ mucosal, two parotid, and two aural tumours; they were often multiple and the frequency did not diminish significantly until 10 years after primary treatment (Table 4).

In the 11 palatal neoplasms, the hard palate was involved in 10 (in most cases primarily) and the soft palate in three. Extension to the alveolar margin occurred in two cases, to the nasal cavity in three, and to the maxillary sinus in five with subsequent involvement of the orbit in two.

Neoplasms arising primarily in the maxillary sinus spread to the nasal cavity in five, to the orbit in four, and to the hard palate in three.

The nasopharyngeal tumours spread to the nasal cavity in two cases, to the palate in two, and to the orbit in one.

Systemic spread was known to have occurred in eight cases, all of which were of mucosal gland origin. The organs involved included the lungs, heart, brain, liver, and skin though histological confirmation was often lacking. Lymph node metastasis occurred in three cases, two being mucosal and one of parotid origin.

Perineural infiltration was found in six of the mucosal gland tumours. Two of the patients died of their disease within five years, one survived for five years without recurrence before dying from an unrelated cause, and another has survived seven years without recurrence. Of the remaining two cases, one has been lost to follow-up, and in the other neural involvement was first observed in a recurrence $\frac{\bar{\sigma}}{\Im}$ after 22 years.

\section{Discussion}

\section{ANATOMICAL DISTRIBUTION}

The literature now contains many reports on these neoplasms and some, such as those of Smout and French (1961) and Smith et al. (1965), have dealt $\stackrel{\unrhd}{\varrho}$ exclusively with this type. The greater number, $\overrightarrow{\vec{D}}$ however, have formed part of larger series including 3 all varieties of mucosal or salivary gland tumours. In the mucosal gland group alone, major series published between 1935 and 1973 include those of Ahlbom (1935), Ringertz (1938), McDonald and Havens (1948), Russell (1955), Ranger et al. (1956), 울 Fine et al. (1960), Chaudhry et al. (1961), Stuteville and Corley (1967), Potdar and Paymaster (1969), and Spiro et al. (1973), while during the same period smaller series were reported by Harvey et al. (1938), 을 Hoboek (1949), Lampe and Zatzkin (1949), Smith et al. (1954), Bhaskar and Weinmann (1955), Edwards (1960), Smith (1962), and Bergman (1969). N These major and minor series gave a total of $1712^{\circ}$ mucosal gland tumours of all types, of which $557 \mathrm{~N}$ $(32.5 \%)$ were cribriform adenocarcinomas. Table $5 \mathrm{w}$ shows the anatomical distribution and relative frequency of this type of neoplasm based on theo above-mentioned series. It is apparent that the anatomical distribution in the present series fits into ${ }^{+}$

the general pattern.
It is generally accepted that this type of adeno- $\frac{0}{\vec{D}}$ carcinoma is more commonly found in mucosal as compared with major salivary glands but precise $\underset{\varrho}{\mathbb{Q}}$ assessment of the relative frequency is difficulto because most series, like the present one, are biased. 
Table 5 Mucosal gland tumours: anatomical distribution and frequency of cribriform adenocarcinomas

\begin{tabular}{|c|c|c|c|c|c|c|c|c|c|}
\hline & \multicolumn{9}{|c|}{ Anatomical location } \\
\hline & Palate & $\begin{array}{l}\text { Oro- } \\
\text { pharynx } \\
\text { mouth }\end{array}$ & Tongue & Tonsil & $\begin{array}{l}\text { Nose and } \\
\text { sinuses }\end{array}$ & $\begin{array}{l}\text { Naso- } \\
\text { pharynx }\end{array}$ & Larynx & Trachea & $\begin{array}{l}\text { Lachrimal } \\
\text { gland }\end{array}$ \\
\hline $\begin{array}{l}\text { Totals (all types) } \\
\text { Cribriform tumours }\end{array}$ & $\begin{array}{l}716 \\
210\end{array}$ & $\begin{array}{l}437 \\
106\end{array}$ & $\begin{array}{r}124 \\
67\end{array}$ & $\begin{array}{r}34 \\
9\end{array}$ & $\begin{array}{l}300 \\
113\end{array}$ & $\begin{array}{l}48 \\
26\end{array}$ & $\begin{array}{r}22 \\
7\end{array}$ & $\begin{array}{r}11 \\
9\end{array}$ & $\begin{array}{l}20 \\
10\end{array}$ \\
\hline Cribriform tumours & & & & & & & & & \\
\hline $\begin{array}{l}\text { \% all types } \\
\text { Cribriform tumours }\end{array}$ & 29 & 24 & 54 & 26 & 37 & 54 & 32 & 82 & 50 \\
\hline Anatomical distribution (\%) & 38 & 19 & 12 & 1.5 & 20 & 5 & 1 & 1.5 & 2 \\
\hline
\end{tabular}

On the other hand, the series reported by Russell (1955), consisting of 42 mucosal and 25 major salivary gland tumours, probably has the smallest element of selection since it is based on attendance at the Holt Radium Institute and, in the context of cribriform adenocarcinoma, the ratio of mucosal to major salivary gland origin was nearly $4: 1$.

STRUCTURE

The light microscopical features have been well documented by many authors, especially Thackray and Lucas (1960). However, it is worth emphasising not only the division into four main patterns (cribriform, tubuloglandular, solid cellular, and hyaline or cylindromatous) which emerged quite clearly in the present series but also the most characteristic of these patterns, the classical cribriform structure. The latter is of sovereign importance not only because its presence is essential to the histological diagnosis but because its pathogenesis offers a clue to the natural clinical behaviour. The evidence of both light and electron microscopy suggests that the cells in such areas are often behaving as though they were partly epithelial and partly connective tissue in type. The PAS negative, hyaluronidase labile metachromatic material in the pseudolumina, originally demonstrated by Azzopardi and Smith (1959), is a product of connective tissue type activity. On the other hand, the tendency of many cells to retain firm intercellular anchorage through the medium of desmosomal attachments is essentially an epithelial characteristic. The occurrence of basement membrane-like material and collagen within the pseudolumina (Friborsky, 1965; Eneroth et al., 1968; Tandler, 1971) also suggests a dual function, as does myoepithelial differentiation. Apposite in this context is the suggestion of Hamperl (1970) regarding the ability of cells to cross the embryological boundary between ectoderm and mesoderm.

It has become a convention to recognise a solid cellular variant of this tumour but in the present series this type of structure was less common than the cribriform pattern, and it is the present author's view that an exclusively solid type of growth with no true cribriform areas should be classified as a malignant basal cell tumour and is probably akin to the solid variant of basal cell cancer of the trachea described by Krompecher (1918) and to the oat cell tumour of Koss et al. (1972). Eneroth et al. (1967) studied adenoid cystic carcinomas arising in the submandibular gland and suggested that the cribriform pattern was associated with a better and the solid pattern with a worse prognosis. In the present series, analysis of those cases ultimately dying of their disease provided no adequate confirmation of such a relationship.

The hyaline or cylindromatous pattern is not always present, thus providing an argument in favour of abandoning the term 'cylindroma'. Furthermore, such a pattern may sometimes be encountered in pleomorphic tumours and hence, striking though this feature may be, it cannot be regarded as a specific one in relation to the cribriform adenocarcinoma. The occasional positive PAS reaction and the electron microscopic appearance are consistent with the possibility that the hyaline material is in part the product of epithelial, basal cell-like activity forming basement membrane substance.

RESEMBLANCE TO TUMOURS IN OTHER SITES Occasionally, tumours of skin appendages may produce a cribriform pattern identical with that in neoplasms of mucosal or salivary glands (Molesworth, 1927; Willis, 1948). When occurring in this location they have often been referred to as cystic basal cell carcinomas and probably have their origin in sweat glands. The so-called adamantinoma of the tibia may well be of similar type, arising in ectopic tissue as originally suggested by Fischer (1913). Occasionally such tumours are seen in the locations of modified sweat glands, comprising breast (Geschickter, 1945; Willis, 1948; Nayer, 1957; Symmers, 1966) and ceruminous glands (Dockerty and Mayo, 1943; Dancot, 1953; Berdal and Mylius, 1954; Smith et al., 1965). Tumours in all these sites probably have a common pathogenesis, but, when 
occurring in the maxillary sinus, the cribriform adenocarcinoma is sometimes confused with the ameloblastoma (Tauxe et al., 1962), and one case in the present series had been initially so diagnosed. The presence of the spider-like cells of the so-called stellate reticulum in the latter tumour is a valuable distinguishing feature.

\section{BEHAVIOURAL CHARACTERISTICS}

The malignant nature of these cribriform tumours is no longer in doubt although their behaviour is variable and data on recurrence, spread, and survival are somewhat confusing. Most published series have recorded systemic involvement though the incidence has varied greatly. Beck and Guttman (1936) reviewed 40 cases with tumours of respiratory tract origin, finding systemic spread in only two patients $(5 \%)$. Dancot (1953) found four in 19 cases involving various sites $(21 \%)$, Struben and Hampe (1959) reported five out of 21 cases of diverse origin $(24 \%)$, while Eneroth et al. (1967) claimed 15 out of 25 submandibular tumours $(60 \%)$. Two of the larger series are less specific on this point. Thus Smout and French (1961) found remote spread in at least 15 of their 65 cases of mixed origin ( $23 \%$ or more) while Smith et al. (1965) reported systemic involvement in at least 18 of their 58 cases from divers sites ( $31 \%$ or more). The largest series, however, is that of Spiro et al. (1973), who recorded remote spread in nearly $40 \%$ of 174 cases of mucosal gland origin and stated that $62 \%$ of distant metastases from all varieties of malignant mucosal gland tumours were from primaries of this particular type. In the present series, the incidence of less than $20 \%$ is undoubtedly an underestimate, having regard to cases lost to follow-up and the fact that necropsies were rarely performed.

Reports on metastases to regional lymph nodes have also shown great variation. Beck and Guttman (1936) reported none among their 40 cases, as did many other authors of smaller series. The highest incidence has been reported in connection with tumours of submandibular origin. Thus, Dockerty and Mayo (1942) recorded an incidence of $26 \%$ of their 15 cases while Eneroth et al. (1967) found lymph node involvement in $32 \%$ of their 25 cases. Among those series of mixed origin, Smout and French (1961) reported an incidence of $10.7 \%$ while Smith et al. (1965) found 17\%. Spiro et al. (1973) found $13.9 \%$ among their 174 mucosal tumours, and it is noteworthy that this was the lowest incidence of lymphatic spread in all types of malignant tumour in their series, contrasting sharply with the high incidence of bloodstream dissemination. Struben and Hampe (1959) drew attention to the minor role of lymphatic spread, a fact also indicated in the present series.

Data on the ultimate fate of this neoplasm often suffer from lack of precision and uniformity, reflecting underlying problems such as size of series and $\overline{0}$ difficulties of follow-up. It is no part of the present $\frac{\bar{D}}{\bar{W}}$ study to assess patterns of treatment and, in making $\frac{\bar{\sigma}}{\vec{D}}$ comparisons, therefore, one is necessarily working $\stackrel{\mathbb{Q}}{\varrho}$ on the premise that therapeutic differences have not $\cong$ been sufficiently profound to cause total invalidation $\vec{D}$ of the attempt to measure malignancy. One kind of such an estimate is apparent in the number of cases $\vec{\omega}$ dying of their tumour. Eneroth et al. (1967) found $\stackrel{\circ}{\Omega}$ $+\infty \%$, Smout and French (1961) reported $56 \%$, 용 Smith et al. (1965) recorded $59 \%$, while Tauxe et al. (1962) claimed $96 \%$. In the present series, the com- $\omega$ parable figure is currently $38 \%$ but none of these $\vec{C}$ percentages can have any precise meaning unless $f$ specifically related to time intervals. The same의 argument would apply to the recurrence rate which, $\rightarrow$ in the present series, now stands at $49 \%$ as com- 3 pared with $67 \%$ reported by Smith et al. (1965) or nearly $100 \%$ found by Tauxe et al. (1962).

Eneroth et al. (1967) expressed the view that $\vec{\theta}$ five-year survival rates were too optimistic. This. could well be concluded from the present series in which the crude survival rates at three, five, and $10 £$ years were respectively $67 \%, 56 \%$, and $38 \%$, and also from the pattern of recurrence shown in Table $4 . \triangleq$ Spiro et al. (1973) reviewed 129 of their cases afterष्ठ 10 years and found a survival rate of $21.7 \%$. These $\overrightarrow{\vec{B}}$ authors also found that 12 out of 52 cases exhibiting recurrence (with secondaries) survived for five years or more, and comparable figures in the presento series would be 10 out of 14 cases, giving a five-year survival rate among recurrent cases of $68 \%$. Al-o though the numbers are small, they serve to em-phasise the point made by the previously mentioned? authors regarding the tendency of many cases of thiso type of neoplasm to survive in spite of recurrence.

An unequivocal feature of malignancy in these tumours is the perineural infiltration (Fig. 8) which has been reported by many workers (Leroux and? Leroux-Robert, 1934; Dockerty and Mayo, 1942 N Belsey and Valentine, 1951; Berdal and Mylius? 1954; Smout and French, 1961). The last-mentioned authors reported an incidence of over $40 \%$ anc emphasised the frequency with which this featur@ could be demonstrated if searched for with diligencee In the present series, only six cases $(14 \%)$ had neura厉 involvement and all were of mucosal gland origin $\stackrel{?}{?}$ Notwithstanding the significance of this event, theo prognosis is clearly difficult to assess.

The higher incidence of malignancy among mucosal as compared with major salivary glan $\frac{\mathbb{D}}{8}$ tumours is largely a reflection of a differing frequency pattern in histological type in which the cribriform 


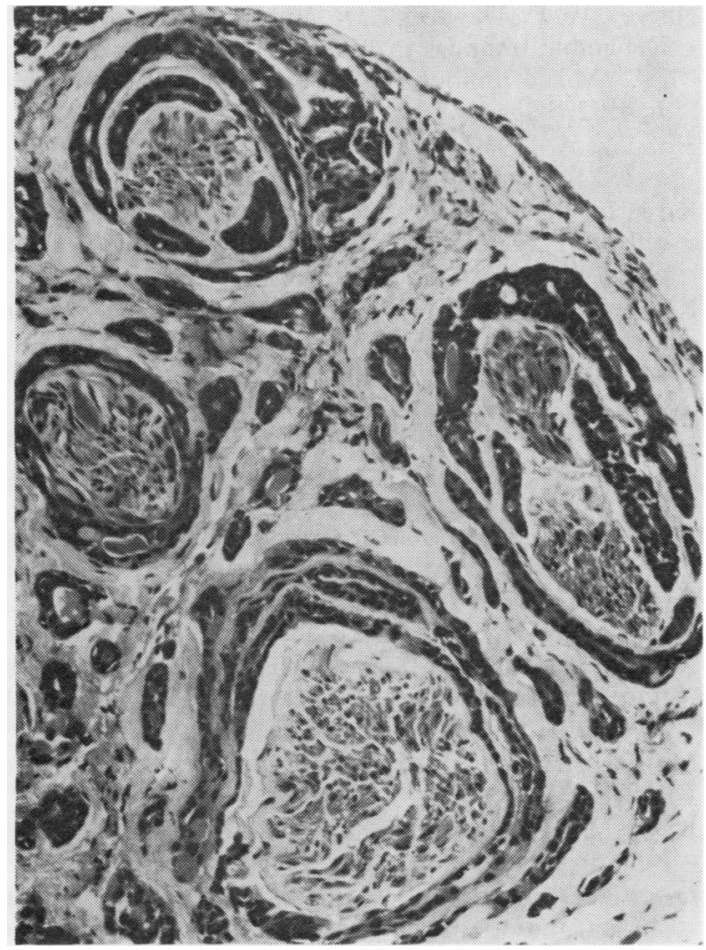

Fig. 8 Case 186. Cribriform adenocarcinoma of maxillary sinus. Perineural infiltration. $H$ and $E \times 200$.

or adenoid cystic carcinomas play an important part, but there is no reason to suppose that they have a higher grading of malignancy in the mucosal gland group. The results of the present analysis conform to the general pattern of published series in so far as comparison is possible. The five-year crude survival rate $(56 \%)$ is loaded adversely in so far as no correction has been made for cases lost to follow-up or for patients dying from unrelated causes. While such a figure may be optimistic in relation to the pattern of recurrence, it nevertheless serves to achieve one of the objectives of this study. Malignant though they are, these cribriform adenocarcinomas appear to be less so, in terms of survival, than other types of carcinoma arising in similar locations. Their less malignant behaviour as compared with other forms of bronchiogenic carcinoma is generally accepted and merits no further comment here. In the upper respiratory tract one may usefully compare the five-year survival rate with that for squamous $(17 \%)$ or even the transitional type $(36 \%)$ carcinoma of the paranasal sinuses (Osborn, 1970). In the commonest site of origin, namely, the palate, the contrast is again evident. Of 31 cases of primary carcinoma of the palatal epithelium collected between 1948 and 1965 , only seven have survived for five years or more $(22.5 \%)$.

\section{Conclusions}

Central to the structural theme and essential to the histological diagnosis is the classical cribriform pattern which appears to represent a tumour, partly epithelial and partly connective tissue in type as regards its development and behaviour. Probably, tumours with a predominant solid cellular growth and an absence of the true cribriform structure do not belong to this type, and the prognostic significance of relative proportions of these two patterns is speculative. The hyaline stromal pattern from which the original name of this neoplasm was derived is not always present nor is it an exclusive feature.

This unquestionably malignant tumour is associated with a survival pattern which does not relate entirely to its histopathological nature and behaviour. Predilection for perineural infiltration must be an important factor in local recurrence but, paradoxically, it does not appear to lead necessarily to a reduction in survival prospects. Comparison with other forms of carcinoma in similar locations indicates better survival of the adenocarcinoma though the recurrence pattern (Table 4) emphasises a not inconsiderable morbidity rate. Tendency to spread via the bloodstream rather than the lymphatic system may be a reflection of its partly mesodermal character while the capacity of recurrent cases to survive suggests the possibility of an immunological response reminiscent of the behaviour of malignant melanomas.

No other neoplasm has acquired so many different labels-basalioma, pseudoadenomatous basal cell carcinoma, adenomyoepithelioma, and cystic adenocarcinoma, to mention but a few additional names. Such a plethora of terms is a sure measure of the uncertainty which has existed concerning the nature of this glandular tumour. While too much time and space should not be wasted in arguments over terminology, there is a case for the retention of the expression cribriform adenocarcinoma on the grounds that, by emphasising the essential histological feature, it may contribute more to the understanding of this intriguing tumour.

The content of this paper formed part of a thesis (MD London) entitled 'The Tumours of the Subsidiary or Mucosal Glands', 1974.

Thanks are due to the surgeons of the Royal National Throat, Nose, and Ear Hospital for access to the clinical records of relevant cases, to Mrs B. Burford for technical assistance, and to $\mathrm{Mr} \mathrm{D}$. Connolly for help with some of the photography. 
References

Ahlbom, H. E. (1935). Mucous and salivary-gland tumours. Acta radiol. (Stockh.), Supplement 23.

Azzopardi, J. G. and Smith, O. D. (1959). Salivary gland tumours and their mucins. J. Path. and Bact., 77, 131-140.

Beck, J. C. and Guttman, M. R. (1936). Basaloma or so-called cylindroma of the air passages. Ann. Otol. (St. Louis), 45, 618-631.

Belsey, R. H. R. and Valentine, J. C. (1951). Cylindromatous mucous-gland tumours of the trachea and bronchi: a report of three cases. J. Path. and Bact., 63, 377-387.

Berdal, P. and Mylius, E. (1954). Cylindromas of the respiratory tract, the upper part of the digestive tract and adjoining organs. Acta oto-laryng. (Stockh.), Supplement, 118, 32-44.

Bergman, F. (1969). Tumors of the minor salivary glands. Cancer (Philad.), 23, 538-543.

Bhaskar, S. N. and Weinmann, J. P. (1955). Tumors of the minor salivary glands. Oral Surg., 8, 1278-1297.

Billroth, T. (1856). Untersuchungen über die Entwicklung der Blutgefässe. G. Reimer, Berlin.

Chaudhry, A. P., Vickers, R. A., and Gorlin, R. J. (1961). Intraoral minor salivary gland tumors. Oral Surg., 14, 1194-1226.

Dancot, H. (1953). Les cylindromes des glandes salivaires. Bull. Ass. franc. Cancer, 40, 383-396.

Dockerty, M. B. and Mayo, C. W. (1942). Primary tumors of the submaxillary gland with special reference to mixed tumors. Surg. Gynec. and Obstet., 74, 1033-1045.

Dockerty, M. B. and Mayo, C. W. (1943). "Cylindroma" (adenocarcinoma, cylindroma type). Surgery, 13, 416-422.

Edwards, E. G. (1960). Tumors of the minor salivary glands. Amer. J. clin. Path., 34, 455-463.

Eneroth, C. M., Hjertman, L., and Moberger, G. (1967). Malignant tumours of the submandibular gland. Acta oto-laryng. (Stockh.), 64, 514-536.

Eneroth, C. M., Hjertman, L., Moberger, G. and Wersall, J. (1968). Ultrastructural characteristic of adenoid cystic carcinoma of salivary glands. Arch. klin. exp. Ohr.-, Nas.-, u. Kehlk.-Heilk., 192, 356-368.

Fine, G., Marshall, R. B., and Horn, R. C., Jr. (1960). Tumors of the minor salivary glands. Cancer (Philad.), 13, 653-669.

Fischer, B. (1913). Über ein primäres Adamantinom der Tibia. Frankfurt Z. Path., 12, 422-441.

Friborsky, V. (1965). Submicroscopical structure of adenoid cystic carcinoma of salivary glands. Acta morph. Acad. Sci. hung., 14, 105-116.

Friedmann, I. and Osborn, D. A. (1966). Malignant tumours of the nasopharynx. In Systemic Pathology, 1st edition, edited by G. P. Wright and W. St. C. Symmers, Vol. 1, p. 313. Longmans, London.

Geschickter, C. F. (1945). Diseases of the Breast, 2nd edition. Lippincott, Philadelphia.

Hamperl, H. (1970). The myothelia (myoepithelial cells). Normal state; regressive changes; hyperplasia, tumors. Curr. Topics Path., 53, 161-220.
Harvey, W. F., Dawson, E. K. and Innes, J. R. M. (1938). Debatable tumours in human and animal pathology IV. "Mixed tumours" of salivary glands. Edinb. med.ल) J., 45, 275-284.

Hoboek, A. (1949). Intraoral mucous and salivary gland mixed tumours. Acta radiol. (Stockh.), 32, 229-247.

Koss, L. G., Spiro, R. H. and Hajdu, S. (1972). Small cell (oat cell) carcinoma of minor salivary gland $\varrho$ origin. Cancer (Philad.), 30, 737-741.

Krompecher, E. (1918). Zur Kenntnis der Basalzellen- $\vec{\circ}$ krebse der Nase, der Nebenhöhlen, des Kehlkopfesund der Trachea. Arch. Laryng. Rhin. (Berl.), 31, $\vec{\omega}$ 443-460.

Lampe, I. and Zatzkin, H. (1949). Pulmonary metastases of pseudo-adenomatous basal-cell carcinoma (mucousic and salivary gland tumor). Radiology, 53, 379-385.

Leroux, R. and Leroux-Robert, J. (1934). Essai de classi- $\stackrel{\omega}{-}$ fication architecturale des tumeurs des glandeser salivaires. Bull. Ass. franc. Cancer, 23, 304-340.

McDonald, J. R. and Havens, F. Z. (1948). A study of malignant tumors of glandular nature found in the nose, throat and mouth. Surg. clin. N. Amer., 28, 1087-1106.

Molesworth, E. H. (1927). Rodent ulcer. Med. J. Aust., 1, 878-899.

Nayer, H. R. (1957). Cylindroma of the breast with. pulmonary metastases. Dis. Chest, 31, 324-327.

Osborn, D. A. (1970). Nature and behaviour of tran-s sitional tumors in the upper respiratory tract. Cancer (Philad.), 25, 50-60.

Potdar, G. G. and Paymaster, J. C. (1969). Tumors ofि minor salivary glands. Oral Surg., 28, 310-319.

Ranger, D., Thackray, A. C., and Lucas, R. B. (1956). Mucous gland tumours. Brit. J. Cancer, 10, 1-16.

Registrar General's Statistical Review of England and Wales for the Year 1970. Part I, Tables, Medical Table 2.

Reid, J. D. (1952). Adenoid cystic carcinoma (cylindroma) of the bronchial tree. Cancer (Philad.), 5, 685-694.

Ringertz, N. (1938). Pathology of malignant tumoursi arising in the nasal and paranasal cavities and maxilla. Acta oto-laryng. (Stockh.), Supplement, 27, 73-75.

Russell, H. (1955). Adenomatous tumours of the anteriors foregut region showing the cylindroma pattern. Brit. JD Surg., 43, 248-254.

Sabatini, D. D., Bensch, K., and Barrnett, R. J. (1963) त Cytochemistry and electron microscopy: the preseros vation of cellular ultrastructure and enzymatic activity

by aldehyde fixation. J. Cell Biol., 17, 19-58.
Smith, A. G., Broadbent, T. R., and Zavaleta, A. A N $_{\sigma}^{N}$ (1954). Tumors of oral mucous glands. Cancer (Philad.) 7, 224-233.

Smith, J. F. (1962). Tumors of the minor salivary glands Oral Surg., 15, 594-602.

Smith, L. C., Lane, N., and Rankow, R. M. (1965) Cylindroma (adenoid cystic carcinoma). Amer. J. Surg. 110, 519-526.

Smout, M. S., and French, A. J. (1961). Prognosis og pseudoadenomatous basal-cell carcinoma: cylindroma adenocystic carcinoma. Arch. Path., 72, 107-112 
Spiro, R. H., Koss, L. G., Hajdu, S. I., and Strong, E. W. (1973). Tumors of minor salivary origin. Cancer (Philad.), 31, 117-129.

Struben, W. H. and Hampe, J. F. (1959). Cylindromas of the upper respiratory tract. J. Laryng., 73, 722-731

Stuteville, O. H. and Corley, R. D. (1967). Surgical management of tumors of intraoral minor salivary glands. Cancer (Philad.), 20, 1578-1586.

Symmers, W. St. C. (1966). Malignant neoplasms of the breast. 1. Carcinoma. Systemic Pathology, 1st edition, edited by G. P. Wright and W. St. C. Symmers, Vol. 1, p. 991. Longmans, London.
Tandler, B. (1971). Ultrastructure of adenoid cystic carcinoma of salivary gland origin. Lab. Invest., 24, 504-512.

Tauxe, W. N., McDonald, J. R., and Devine, K. D. (1962). A century of cylindromas. Arch. Otolaryng., 75, 364-376.

Thackray. A. C. and Lucas, R. B. (1960). The histology of cylindroma of mucous gland origin. Brit. J. Cancer, 14, 612-620.

Willis, R. A. (1948). Epithelial tumours of the skin. In Pathology of Tumours, 1st edition, Ch. 14, p. 258. Butterworth, London.

\section{The February 1977 Issue}

\section{THE FEBRUARY 1977 ISSUE CONTAINS THE FOLLOWING PAPERS}

Does preoperative iodide treatment for thyrotoxicosis bring about involution? T. J. WILKIN, J. SWANSON BECK, AND W. MICHIE

Acinar cell neoplasms of the exocrine pancreas J. N. WEBB

Features of prognostic significance in testicular germ cell tumours CONSTANCE PARKINSON AND J. $O$. W. BEILBY

Malignant histiocytosis (histiocytic medullary reticulosis) with spindle cell differentiation and tumour formation J. B. MacGILLIVRAY AND J. S. DUTHIE

Rectal biopsy as a prognostic guide in Crohn's colitis M. WARD AND J. N. WEBB

Alpha-1-antitrypsin bodies in the liver $\mathbf{w}$. $\mathbf{K}$. BLENKINSOPP AND G. P. HAFFENDEN

A shorter immunoperoxidase technique for the demonstration of carcinoembryonic antigen and other cell products EADIE HEYDERMAN AND A. MUNRO NEVILLE

Frequency of renal impairment in paracetamol overdose with other causes of acute liver damage S. P. WILKINSON, HELEN MOODIE, V. A. ARROYO, AND ROGER WILLIAMS

25-Hydroxyvitamin D levels in patients treated with high-dosage ergo- and cholecalciferol J. M. GERTNER AND MERCEDES DOMENECH

Use of umbelliferone derivatives in the study of enzyme activities of mycobacteria J. M. GRANGE AND KATHY CLARK

An evaluation of the Modified R/B Enteric Differential System for the identification of the Enterobacteriaceae

L. J. HAYEK AND G. W. WILLIS
Improving the performance of anaerobic bacteriology in a hospital laboratory J. R. MORGAN, J. A. SMITH, AND P. LIU

Drug resistance in relation to use of silver sulphadiazine cream in a burns unit KIM BRIDGES AND E. J. L. LOWBURY

An outbreak of infection caused by a gentamicinresistant Staphylococcus aureus A. J. BINT, R. H. GEORGE, D. E. HEALING, R. WISE, AND M. DAVIES

Serological grouping of streptococci by a slide coaggulation method ROGER G. FINCH AND IAN PHILLIPS

Automation of the rapid plasma reagin (RPR) test using the autotape system (AS) J. R. BOOTH, P. J. L. SEQUEIRA, W. WAGSTAFF, I. HOPKINSON, D. GIBBS, AND E. BENNETT

Screening of blood donors for the detection of antitetanus antibodies suitable for the production of human antitetanus immunoglobulin J. C. WISEMAN AND M. E. GASCOIGNE

Red cell indices and serum ferritin levels in children JILL HOWS, SONAY HUSSEIN, A. V. HOFFBRAND, AND S. N. WICKRAMASINGHE

Congenital dyserythropoietic anaemia: response to splenectomy and quantitation of ineffective erythropoiesis DIANA SAMSON, D. HALLIDAY, AND I. CHANARIN

\section{Technical method}

A semiselective medium for the isolation of Vaillonella species from the mouth T. WALLACE MaCFARLANE

Book reviews

Copies are still available and may be obtained from the PUBLISHING MANAGER, 